\title{
The fraction of a political party is an important subject of the legislative process
}

\section{Ikhtiyor BEKOV 1 \\ Tashkent State University of Law}

\begin{tabular}{l} 
ARTICLE INFO \\
\hline Article history: \\
Received May 2021 \\
Received in revised form \\
20 May 2021 \\
Accepted 15 June 2021 \\
Available online \\
15 July 2021 \\
\hline
\end{tabular}

\footnotetext{
Keywords:

political party,

fraction,

legislative process,

Legislative Chamber of the

Oliy Majlis,

lawmaking,

bill,

legislative initiative.
}

\begin{abstract}
The article examines the legal mechanisms associated with the participation of fractions of political parties in the legislative process. The legislative activity of fractions of political parties in the Legislative Chamber of the Oliy Majlis has been analyzed with the help of reliable statistics. The legislative activity of the fractions of political parties in the Legislative Chamber of the Oliy Majlis is analyzed by accurate statistics. The article provides suggestions for improving the participation of fractions of political parties in the legislative process.
\end{abstract}

2181-1415/C) 2021 in Science LLC.

This is an open access article under the Attribution 4.0 International (CC BY 4.0) license (https://creativecommons.org/licenses/by/4.0/deed.ru)

\section{Сиёсий партия фракцияси - қонун ижодкорлиги жараёнининг мухим субъекти}

\section{Калит сўзлар:}

сиёсий партия,

фракция,

қонунчилик жараёни,

Олий Мажлис Қонунчилик

палатаси,

қонун ижодкорлиги,

қонун лойихаси,

қонунчилик ташаббуси.

\begin{abstract}
АННОТАЦИЯ
Ушбу мақолада сиёсий партиялар фракцияларининг қонунчилик жараёнидаги иштироки билан боғлиқ хуқуқий механизмлари тадқиқ этилган. Унда сиёсий партиялар фракцияларининг қонунчилик жараёнидаги иштироки босқичларга бўлиб ўрганилган. Олий Мажлис Қонунчилик палатасидаги сиёсий партиялар фракцияларининг қонунчилик фаолияти аниқ статистик рақамлар орқали тахлил этилган. Мақолада сиёсий партиялар фракцияларининг қонунчилик жараёнида иштирокини такомиллаштиришга оид таклифлар билдирилган.
\end{abstract}

\footnotetext{
${ }^{1}$ Independent researcher, Tashkent State University of Law, Tashkent, Uzbekistan.
} 


\section{Фракция политической партии - важный субъект законодательного процесса}

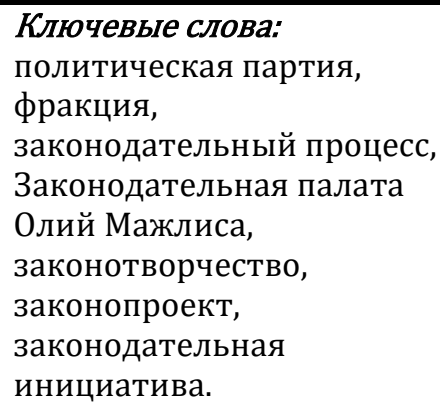

\begin{abstract}
АННОТАЦИЯ
В статье исследуются правовые механизмы, связанные с участием фракций политических партий в законодательном процессе. В нем поэтапно изучено участие фракций политических партий в законодательном процессе. Законодательная деятельность фракций политических партий в Законодательной палате Олий Мажлиса проанализирована на основе точных статистических данных. В статье приводится предложения по улучшению участия фракций политических партий в законодательном процессе.
\end{abstract}

It is known that the legislative power is a type of "visiting card" of the modern parliament, and all other areas of its activity stem from this main direction, which is intended to create the necessary conditions for its provision. It should be acknowledged that no other body can replace parliament in lawmaking, because its nature and essence, the procedures applied, the forms and methods of resolving issues are explained by the characteristics of this parliamentary activity. Of course, the fact that it is a representative body is also essential in this regard.

The characteristics of a political party's activity in parliament are reflected in the fact that they are the subject of both political processes and the electoral process. In these cases, the legalization of a political party as an integral part of the representative body of state power is carried out on the basis of the principle of state power, and thus the political party has the opportunity to have a real impact on the exercise of state power. The participation of parliamentary fractions and party groups in local representative bodies in lawmaking is the most important area of their activity. The ability to implement its political goals and objectives, first of all, in the sphere of legislation, is a bright indicator of professionalism in the work of this deputy association and its members. Deputy party associations, in accordance with their political priorities, strive for the adoption of laws on the basis of legislative initiatives of their members, as well as with the participation of their representatives in committees.

The participation of fractions of political party in the lawmaking process is its main function. In this sphere, legislation requires constant and rapid interaction of public authorities with individuals with up-to-date information and knowledge. At the same time, the fractions of political parties, depending on the political direction and their electorate, perform the function of studying and analyzing social phenomena and processes in lawmaking, creating the need for legal regulation.

This sphere has been consistently studied by researchers in recent years. In particular, such scholars E. Shulman [1], K. Djavakova [2], I. Chesnokov [3], B. Oyland, S. Obolt, S. Hicks [4] have made constructive proposals to further expand the participation of fractions of political parties in lawmaking process.

Summarizing the views of these scholars, it can be said that the activities of fractions in the sphere of lawmaking are the most socially effective method for a democratic society against the background of multifaceted interests as an institution of presentation of electorate. 
In analyzing the legislative function of the Oliy Majlis, it is necessary to pay attention to the use of different terms to describe this function. These include: "legislative function", "legislative process", "lawmaking", "rule making”, etc. [5]. The most appropriate term for the analysis of our study is the concept of "lawmaking". Rulemaking reflects not only the laws, but also the whole process of lawmaking, the concept of "rule making" has a broader meaning than "lawmaking" and provides a basis for distinguishing these concepts. Professor V.K. Babayev describes lawmaking as "the procedure for the official origin of a draft normative document in the legislature" and distinguishes legislative initiative "it includes the stages of discussion, adoption and promulgation of the bill" [6]. The legislative activity emphasizes the creative side of this process, so this concept also includes the initiative to develop draft laws implemented by entities that do not have the right to initiate legislation - political parties. However, parties can act as such initiators through their parliamentary fractions.

It is known that such an initiative can be in the form of a proposal for the preparation and adoption of the law, or in the form of submission, introduction of the finished text of the bill [7]. According to B. Ismoilov, "there are differences between the bill and the legislative proposal to draft law, which can be seen in the full sense of the word: the first, the text of the future law contains all the attributes (preamble, articles, paragraphs, paragraphs, norms), the second refers to put forward a legislative proposal. Of course, it is better to include all the attributes of the bill [8]".

The Constitution defines the range of subjects entitled to legislative initiative. In our opinion, there is a need to expand the range of subjects of legislative initiatives. First of all, due to the expansion of the people's initiative on the rule of law, it is expedient to give the right to such an initiative to political parties. The institute of public legislative initiative is applied, for instance, in Austria, Spain, Italy and Switzerland. In Switzerland, in particular, major legislative initiatives have been introduced by political parties in recent years [9]. We think that political parties may raise the issue of adopting a new law. Political parties have a large number of members, they are more organized than the usual citizens' associations, they have human, material, organizational and other resources. For this reason, we consider it appropriate to introduce a rule in our legislation that would give political parties the power to initiate the adoption of new laws or amendments to existing laws.

K. Javakova, a scientist who has published a number of scientific works in this sphere, believes that the types of forecasting and planning of fractions of political party play an important role in the lawmaking process [10].

While the participation of fractions of political party in the lawmaking process requires the development of scientifically based positions through forecasting, planning creates the rights and freedoms of fractions in the development of certain rules.

In this regard, it can be said that the political party carries out forecasting for a period of five years, taking into account the socio-economic development of the state and society by modeling the future laws. In addition, international standards, such as the UN Sustainable Development Goals, can also be a source of forecasting.

In the process of working on the bill, the fractions of the political parties in parliament compete with each other and, accordingly, create this competitive environment, which is a key element in improving the quality of the legislative process. Fractions and groups of the political parties can participate in the development and 
revision of the bill at almost every stage, making suggestions and objections to its content. A conciliation commission may be set up to resolve disputes and disagreements concerning the bill, in which fractions may nominate their candidates from the Legislative Chamber.

The action plan of the parliament is essential in the lawmaking process of the fractions of political parties. Based on the experience of developed foreign countries in this regard, it can be said that the issue of ensuring the compromise of fractions is separately regulated by the parliament. In particular, the Bundestag in Germany and the Speaker in South Korea take into account the interests of fractions in the development of the parliamentary action plan.

It is worthy to noted that the legislative function by the representative bodies is not yet perfect enough, and improving its quality and efficiency is still relevant today. Deficiencies in the concept of improving the rulemaking activity, approved by the Decree of the President of the Republic of Uzbekistan on August 8, 2018 No. PF-5505, lead to the continuation of the negative practice of scattered regulation of social relations in various spheres, which leads to legal conflicts, leading to different interpretations and complexities in application. The need to increase the impact of public discussions on the creation of laws through the effective organization of the broad involvement of citizens, civil society institutions, Mass Media, businesses and science in this process was emphasized. We stress out that the important role of fractions and groups of political parties that are able to involve their electorate in the process of evaluation and discussion of bills.

Announcement of bills by fractions and groups of political parties allows to inform the electorate, public associations, citizens about the legislative activity in a timely manner. In addition, it will provide public control over their implementation, organize public discussions of the most important bills in MassMedia, scientific conferences. [11]. One of the most important issues in the enforcement of the adopted law is to help citizens to develop a sense of involvement in lawmaking. Therefore, in order to increase the effectiveness of the legislative activity of fractions, it is necessary to achieve transparency in the continuous development, adoption and enforcement of the system of legislative control of institutions of civil society.

It should be noted that the discussion of bills by fractions of political parties in parliament with the electorate is important in a comprehensive and complete consideration. These discussions provide an opportunity to draw the attention of the general public to the results of the legislative process in the interests of the electorate. In addition, the digitization of the process of discussion with the electorate is crucial in lawmaking of fractions of political party. A number of researchers, in particular, D. Pashentsev [12], M. Zaloilo [13], S. Petrova[14], D. Birjanova [15] N. Bobrova, V. Sidorov[16], M. Adams, C. Prins [17] put forward the idea of digitalization of legislation and expanding the participation of political parties in it. Studies show that in 2020, joint work was organized by the parliamentary fraction of the People's Democratic Party of Uzbekistan in the process of preparing important social, socio-economic bills for the second reading to discuss with citizens on the ground, to study their attitudes and take into account the suggestions and comments of citizens. As a result of this cooperation, 85 meetings and roundtables were held to discuss draft laws. They took into account 280 suggestions made by citizens in the process of drafting laws. 
The section "Bills" in the official website of the People's Democratic Party of Uzbekistan (www.xdp.uz) has been opened, which regularly publishes bills considered by the Legislative Chamber. In particular, the draft laws "On Education", "On Guarantees of the Rights of Persons with Disabilities", "On Employment" and more than 15 other social issues were posted on the party's website for discussion, and suggestions from the electorate and citizens were received.

During the reporting period, members of the fraction of the People's Democratic Party of Uzbekistanannounced articles and posts a total of 6,053, including 402 on television, 75 on radio, 427 in the press, 5,149 on websites and all social networks. were reviewed [18].

The analysis of problems in the legislative activity in the Republic of Uzbekistan by the international non-profit organization "Buyuk Kelajak" in the first half of 2019 shows that the level of activity of fractions is an important component of parliamentarism. In particular, one of the important features of parliamentarism is that issues related to human and civil rights and freedoms need to be regulated with law. This, in turn, increases the need for fractions to involve experts in the development of directly applicable laws, as well as the general public.

Legislative activity is a complex process that requires from its participants not only certain experience in this sphere, but also relevant knowledge and skills. Therefore, it is necessary to train lawmaking subjects, to form in them the skills and professionalism required in this specific activity. Of course, it would be a utopia to want to make every MP a lawyer. However, the elimination of legal illiteracy and legal nihilism is one of the conditions for the development of legal culture, as well as lawmaking.

Based on the above, in order to ensure the scientific basis of the activities of the fractions, it is proposed to establish Public Councils under them, consisting of specialists with sufficient knowledge and skills and experience. The Public Council under the fractions of political parties assists in the implementation of the forecasting function of the fraction. By giving a scientifically based conclusion to the bill by the Council, the near and long-term position of the political party is achieved through the approbation of the party electorate.

It is also advisable today to consistently implement cooperation between political parties in the sphere of lawmaking between non-governmental non-profit organizations and other institutions of civil society. Based on the concept of civil society development in 2021-2025, approved by the Decree of the President of the Republic of Uzbekistan No. PF-6181, on March 4, 2021, it is planned to introduce the institution of permanent representative of non-governmental organizations in the Legislative Chamber of the Oliy Majlis. It is expedient to include specific rights and obligations of this representative to raise issues, ask questions, make proposals and substantiate their objections at the meetings of scientific expert fractions of the political party.

From our point of view, the following main stages of preparation of the bill with the participation of parties or their representatives in the form of fractions can be distinguished:

1. The development of any bill begins with the idea of a law. The fractions of political party have the right to make proposals for the development of legislative acts as an initiator, submit them to the house for consideration. A fractions of orgroups of political parties may decide to include the issue of drafting a new law with the preparation of relevant analytical materials, regulations and other necessary materials. 
Usually, a working group is formed to prepare the bill. Experienced members of the fractions can participate in the preparation. Academician S.S. Alekseev expressed the following views on the need to involve legal professionals: "The law, as an invention, like any achievement of the human mind, must be created by talented people. Real laws cannot be created by large communities. It is necessary to involve people who think constructively in the development of laws [19]". It is at this stage that parties can demonstrate their work - organize public hearings on the issue, involving the necessary experts from their members and supporters, identifying the problem that justifies the need to pass the bill, which needs to be addressed in the legislation.

2. Making proposals to the subjects of the right of legislative initiative by the interested parties on the development of the bill, for instance bringing the idea of a new law to the attention of the deputies of the Legislative Chamber. Parties or party associations in the representative body may hold public discussions on the adoption of a normative legal act, evaluation of the bill, etc.

3. They may formally submit to the subject of the right of legislative initiative the text of a bill or other resolution of the parliament which is binding on the enforcement of the legislative initiative.

Important components and factors of the lawmaking mechanism are also evident in its sociological aspect. There are two main, relatively independent components to this approach: 1) a mechanism for identifying and taking into account social interests and needs; 2) the mechanism of reflection, registration of the identified interests and needs in the bill. The lawmaking process includes consideration, analysis, generalization of proposals for improving the legislation, organizational measures to improve this activity. Because without these efforts, it is impossible to imagine lawmaking process.

In accordance with the established practice, the legislative process begins from the moment the bill is submitted to the Legislative Chamber of the Oliy Majlis and ends with the approval by the Senate of the Oliy Majlis and its signing by the President. In general, lawmaking in Uzbekistan is a classic process, which is typical of countries with a bicameral parliamentary system, one of which is professional and permanent. In the Legislative Chamber, fractions and groups of party take an active part in the process of adopting bills, as the Senate, which approves a law passed by the lower house, does not provide for such structures. We support the following opinion of E.M. Shulman in this regard: The participation of the fractions in the law making "creates great opportunities for the planning, writing bills in parliament". In addition, the fractions (groups) of political parties are interested in the successful participation of "their" deputies in the legislation, provided that the interest of the deputy in them is not very high" [20].

Consideration of the bill shall be carried out in accordance with all procedures provided for in the Constitution and laws, Regulations of the chambers of the Oliy Majlis. After submitting the bill to the Legislative Chamber, the Speaker appoints the committee responsible for conducting the preliminary consideration of the bill. At the same time, fractions and deputy groups will participate in the preliminary consideration of the bill. Work on the bill to develop proposals on the possibility of adopting the bill for consideration by the Legislative Chamber is carried out simultaneously by the fractions and the responsible committee. In this case, the responsible committee does not have the right to draw its own conclusions on the bill without the views and suggestions of the fractions. Based on the conclusion of the responsible committee, the Council of the 
Legislative Chamber, taking into account the views and proposals of the fractions, decides to accept the bill for consideration by the Legislative Chamber or return it to the subject of the right of legislative initiative [21].

The responsible committee will hold a preliminary discussion of the bill, taking into account the views and suggestions of fractions and expert groups, and within two months from the date of receipt of the bill, the Legislative Chamber with the views and suggestions of fractions. It should be noted here that the fractions have right to submit an alternative version of the bill for discussion. If alternative editions of bills are included in the discussion of the Legislative Chamber, they must be considered at the same time. The bill, which received the largest number of votes required for the decision of the deputies of the Legislative Chamber, is considered adopted in the first reading [22].

During the first reading of the bill in the Legislative Chamber, the need for its adoption, the concept of the bill, its compliance with the Constitution and laws of the Republic of Uzbekistan, as well as the costs associated with the implementation of the law and funding sources will be discussed. In this case, the rapporteur must convey to the deputies the views and proposals of the fractions in the first and subsequent readings of the responsible committee. Based on the results of the discussion, the Legislative Chamber shall decide on the adoption of the draft law in the first reading or on the rejection of the draft law, with a mandatory deadline for its submission to the Chamber for finalization and consideration in the next reading.

In preparing the bill for the second reading, the responsible committee sends the text of the bill to the fractions for their opinions and suggestions. Based on their programmatic objectives, the fractions organize the discussion of bill with the participation of citizens on the ground and the study of proposals received on them with the involvement of representatives of relevant organizations of political parties. The fractions will discuss the ideas and proposals received at the end of the study at their meetings, develop proposals based on their programmatic objectives, which will be sent to the responsible committee [23].

Experts say that the effectiveness of legislative activity depends on how deputies and fractions in parliament struggle with each other actively [24]. The activities of party fractions in parliament, their positions in the discussion and adoption of legislation have a significant impact on the quality of adopted legal documents. At the same time, interfractional relations should be distinguished by enlightenment and tolerance, which should be built on a strict legal basis.

In the process of legislative activity of the Legislative Chamber, the fractions use the following opportunities:

- speeches of deputies of the fraction at the plenary sessions of the Chamber and meetings of specialized committees;

- voting at the plenary sessions of the Chamber;

- issue statements and appeals to the deputies of the Chamber to express their views;

- holding hearings, conferences, seminars, "round tables";

- meetings of fraction leaders, as well as members of the fraction with officials of the executive power;

- inviting representatives of public authorities and administration to extended meetings of fractions;

- visits of deputies of the fraction to the regions for meetings with electorate and heads of local authorities;

- work with appeals of legal entities and individuals; 
- interaction with mass media;

- international relations, participation in the CIS Interparliamentary Assembly, etc.

E.M. Shulman singled out six factors of effective law-making: the competence of parliament; independence of parliament from external pressure; the association of deputies within the parliament and the independence of the deputy and sufficient legislative powers; creation of a platform (environment) by the parliament for cultural debates on various issues and legal coordination (agreement) of interests; access of foreign independent experts to the legislative process; transparency of parliamentary activities [25]. In our opinion, in practice, all these factors can be used by party structures established in the representative bodies in the process of legislative activity. Their skillful use, as shown in practice, allows the parties to draw the attention of their electorate to the parliamentary activities.

Taking into account the tasks outlined in the Address of the President of the Republic of Uzbekistan Sh. Mirziyoyev in 2020, it should be noted that the quality and effectiveness of the legislative process largely depends on how parliamentarians are able to conduct their activities proactively, freely, and use tools such as independent expertise, media attention, and public opinion. Thus, the open discussion and public discussion of the draft law has a positive impact on its quality, such discussions and debates are conducted with the involvement of the most stakeholders. The legislative functions of the party structures in the representative bodies are aimed at ensuring a comprehensive discussion of the bill by the fraction. It should be noted that this work is an additional channel for the discussion of the bill, the importance and effectiveness of which largely depends on the activities of party structures and the involvement of public attention (electorate, civil society institutions, etc.) in lawmaking processes.

Law making is a decisive factor in the activities of political parties in parliament, as well as in extra-parliamentary forms of oversight, such as electoral, propaganda and advocacy. At present, regardless of the party's opinion, it is rare for a deputy to freely discuss draft laws in which he or she expresses his or her views. Often the deputy is subject to party discipline and voting according to a position predetermined by the party fraction, which indicates the growing role of party structures in the activities of representative bodies. Of course, every deputy has the right to freely express opinion on the bill at a meeting of the fraction, but he will have to vote in parliament, taking into account the party program and the instructions of the party structures in parliament. Party structures at all stages of lawmaking, including in determining the need for the adoption of the law, the need for it; in the preparation of the law; in exercising the right of legislative initiative; participates in the discussion, and adoption of the law in the lower house of parliament. However, the issue of increasing the activity of fractions at these stages is still relevant. In particular, the results of a survey of experts show that $61.3 \%$ of respondents said that the activity of fractions of political parties in the lower house of the Oliy Majlis is not at the level of today's requirements, and only $11.8 \%$ positively assessed this activity. 20.7 per cent of respondents said they did not have enough information on the subject and 5.5 per cent said they did not have information at all. The figures quoted suggest serious consideration in this regard. In particular, more than $26 \%$ of respondents are concerned about the lack of information on the activities of fractions, indicating that there are serious problems with media coverage of parliamentary activities. 
In conclusion, the participation of fractions of political party in the legislative process promotes the interests of political parties and the electorate at all stages of the process through meetings, online discussions, political party websites, as well as innovative communication platforms with experts and civil society institutions.

\section{REFERENCE:}

1. Шульман Е.М. Фракции, комитеты, аппарат: Участие парламентских партий в законотворческом процессе // Политическая наука. - 2015. - №. 1.

2. Джавакова К.К вопросу повышения эффективности участия партийных фракций в законотворческой деятельности // Fuqarolik jamiyati. Гражданское общество. - 2016. - Т. 13. - №. 4. - С. 63-67.

3. Чесноков Д.Г. Сравнительный анализ реализации достижения целей социально-политических программ двух парламентских партий КПРФ и «Справедливая Россия» // Экономика и социум. - 2020. - №. 8. - С. 343-354.

4. Høyland B., Hobolt S., Hix S. Career ambitions and legislative participation: the moderating effect of electoral institutions // British Journal of Political Science. - 2019. Т. 49. - №. 2. - С. 491-512.

5. Одилқориев Х., Тультеев И. Икки палатали парламент. - Т., 2005. - Б. 82-83.

6. Теория государства и права / Под ред. В.К. Бабаева. - М.: Юристъ, 2012. С. 330-331.

7. Одилқориев Х.Т. Ўзбекистон Республикасида қонун чиқариш жараёни. - Т., 1995. - Б. 87-88. Ўша муаллиф: Конституция ва баркамол жамият орзуси. Т., 2012. Б. 313.

8. Исмаилов Б.И. Реализация права законодательной инициативы в правоприменительной практике зарубежных стран и Республики Узбекистан. - М., 2008. - С. 34.

9. Законодательные инициативы и политические партии в Швейцарии // https://www.swissinfo.ch/rus.

10. Джавакова К. К вопросу повышения эффективности участия партийных фракций в законотворческой деятельности // Fuqarolik jamiyati. Гражданское общество. - 2016. - Т. 13. - №. 4. - С. 63-67.

11. Худайбердиев А. Парламентда қонун ижодкорлиги жараени // Фалсафа ва хуқуқ. - 2005. - № 1. - С. 65-69.

12. Пашенцев Д.А. Российская законотворческая традиция перед вызовом цифровизации // Журнал российского права. - 2019. - №. 2 (266).

13. Залоило М.В. Некоторые вопросы цифровизации процедур оценки проектов нормативных правовых актов // Российское государствоведение. - 2018. - №. 4. - С. 138-149.

14. Петрова С.В. Политические процессы в Российской Федерации в условиях глобальной цифровизации // Государственное и муниципальное управление. Ученые записки. - 2019. - №. 4.

15. Биржанова Д.М. Перспективы демократизации нормотворчества на основе процесса цифровизации // Вестник Института законодательства и правовой информации Республики Казахстан. - 2018. - №. 3 (52). 
16. Bobrova N., Sidorov V. Leading Provisions of the Digitalization, Law, and Science // 6th International Conference on Social, economic, and academic leadership (ICSEAL-62019). - Atlantis Press, 2020. - PP. 317-322.

17. Adams M., Prins C. Digitalization through the lens of law and democracy // Digital democracy in a globalized world. - Edward Elgar Publishing, 2017.

18. Ўзбекистон Халқ демократик партияси фракциясининг 2020 йилдаги фаолияти юзасидан Хисоботи. Ўзбекистон Республикаси Олиқ мажлиси Қонунчилик палатасининг жорий архиви материаллари.

19. Алексеев С.С. Проблемы теории права. Т.2. - Свердловск, 1973. - С. 16.

20. Шульман Е.М. Фракции, комитеты, аппарат: участие парламентских партий в законотворческом процессе / Политическая наука. 2015. № 2. - С. 180. // https://cyberleninka.ru/article/n/fraktsii-komitety-apparat-uchastie-parlamentskihpartiy-v-zakonotvorcheskom-protsesse.

21. Law of Republic of Uzbekistan On the Rules of Procedure of the Legislative Chamber of the Oliy Majlis of the Republic of Uzbekistan 23.08.2003 No. 522-II // https://www.lex.uz/acts/39573.

22. Law of Republic of Uzbekistan On the Rules of Procedure of the Legislative Chamber of the Oliy Majlis of the Republic of Uzbekistan 23.08.2003 No. 522-II // https://www.lex.uz/acts/39573.

23. Law of Republic of Uzbekistan On the Rules of Procedure of the Legislative Chamber of the Oliy Majlis of the Republic of Uzbekistan 23.08.2003 No. 522-II // https://www.lex.uz/acts/39573.

24. Файзиев Ш. Х. Қонун ижодкорлиги жараёнини такомиллаштириш: миллий ва хорижий тажриба. Монография - Т., 2020. - Б. 6.

25. Шульман Е.М. Политические условия и факторы трансформации законотворческого процесса в современной России: автореф. дис. ... канд. полит наук. - М., 2013. - С. 11. 